\title{
Reserve Accumulation Is Prioritized Over Growth Following Single or Combined Injuries in Three Common North American Urban Tree Species
}

\author{
Jorge Andres Ramirez ${ }^{1,2 *}$, Valentina Vitali²,3, Jordi Martínez-Vilalta ${ }^{4}$, I. Tanya Handa ${ }^{2,5 t}$ \\ and Christian Messier $2,5,6+$ \\ ' Facultad de Ciencias Agrarias, Universidad del Cauca, Popayán, Colombia, ${ }^{2}$ Centre d'Étude de la Forêt (CEF), Université \\ du Québec à Montréal, Montreal, QC, Canada, ${ }^{3}$ WSL Research Unit Forest Dynamics, Research Group Ecosystem-Ecology \\ Swiss Federal Institute for Forest, Snow and Landscape Research WSL, Birmensdorf, Switzerland, ${ }^{4}$ CREAF, Universitat \\ Autònoma de Barcelona, Bellaterra, Spain, ${ }^{5}$ Faculté des Sciences, Département des Sciences Biologiques, Université du \\ Québec à Montréal, Montreal, QC, Canada, ${ }^{6}$ Institut des Sciences de la Foret Tempérée, Université du Québec en \\ Outaouais, Ripon, QC, Canada
}

OPEN ACCESS

Edited by:

Penny J. Tricker

University of Adelaide, Australia

Reviewed by:

Gary Johnson,

University of Minnesota Twin Cities,

United States

Alessio Collalti,

National Research Council (CNR), Italy

*Correspondence:

Jorge Andres Ramirez j.ramirez@unicauca.edu.co

tThese authors share senior authorship

Specialty section: This article was submitted to

Plant Abiotic Stress,

a section of the journal

Frontiers in Plant Science

Received: 26 May 2021

Accepted: 19 July 2021

Published: 06 August 2021

Citation:

Ramirez JA, Vitali V Martínez-Vilalta J, Handa IT and Messier C (2021) Reserve Accumulation Is Prioritized Over Growth Following Single or Combined Injuries in Three Common North American Urban Tree Species.

Front. Plant Sci. 12:715399. doi: 10.3389/fpls.2021.715399
Trees that grow in urban areas are confronted with a wide variety of stresses that undermine their long-term survival. These include mechanical damage to the crown, root reduction and stem injury, all of which remove significant parts of plant tissues. The single or combined effects of these stresses generate a complex array of growth and ecophysiological responses that are hard to predict. Here we evaluated the effects of different individual and combined damage on the dynamics of non-structural carbohydrates (NSC, low weight sugars plus starch) concentration and new tissue growth (diameter increment) in young trees. We hypothesized that (i) tissue damage will induce larger reductions in diameter growth than in NSC concentrations and (ii) combinations of stress treatments that minimally alter the "functional equilibrium" (e.g., similar reductions of leaf and root area) would have the least impact on NSC concentrations (although not on growth) helping to maintain tree health and integrity. To test these hypotheses, we set up a manipulative field experiment with 10-yearold trees of common urban species (Celtis occidentalis, Fraxinus pennsylvanica, and Tilia cordata). These trees were treated with a complete array of mechanical damage combinations at different levels of intensity (i.e., three levels of defoliation and root reduction, and two levels of stem damage). We found that tree growth declined in relation to the total amount of stress inflicted on the trees, i.e., when the combined highest level of stress was applied, but NSC concentrations were either not affected or, in some cases, increased with an increasing level of stress. We did not find a consistent response in concentration of reserves in relation to the combined stress treatments. Therefore, trees appear to reach a new "functional equilibrium" that allows them to adjust their levels of carbohydrate reserves, especially in stems and roots, to meet their metabolic demand under stressful situations. Our results provide a unique insight into the carbon economy of trees facing multiple urban stress conditions in order to better predict long-term tree performance and vitality.

Keywords: non-structural carbohydrates, storage, growth, stress, urban forest, Celtis occidentalis, Fraxinus pennsylvanica, Tilia cordata 


\section{INTRODUCTION}

Trees are among the most valuable components of urban green areas due to the wide range of environmental, social, cultural, and economic benefits they provide (Konijnendijk et al., 2005). Nevertheless, urban trees are often facing both biotic and abiotic damage, which affect their health and integrity from canopy to root level. Such damage includes defoliation by insects and wind-breakage, stem damage due to frost or injuries leading to loss of woody tissues and transport capacity (Sieghardt et al., 2005), as well as root damage due to road and house repair and construction (North et al., 2017). Gray infrastructure often limits the growing space of trees, and when combined with compacted soils, water and atmospheric pollution, further exacerbates the stress conditions caused by various damage (Konijnendijk and Randrup, 2004; Tubby and Webber, 2010). Additionally, other damage such as girdling, or ring-barking, often occurs from bicycles chained to street trees, lawn mowers, weed trimmers and human vandalism (Moore, 2013; Purcell, 2014).

Tissue loss changes the growth (the annual change in standing biomass accumulated) and allocation patterns between aboveand below-ground tree components, affecting the functional balance of the tree (Quentin et al., 2012; Wiley et al., 2017; Dong et al., 2019). The reduction in photosynthetic tissue leads to a decrease in carbon resources produced, and in photosynthates available for growth and reserve accumulation (Handa et al., 2005; Wiley et al., 2013; Atkinson et al., 2014; Deslauriers et al., 2015). Severe defoliation may even cause root mortality by decreasing metabolic activity (e.g., water and nutrient uptake) (Snyder and Williams, 2003). Root reduction causes a deficiency of water and nutrients reducing photosynthetic metabolism (Dong et al., 2016). Additionally, root reduction removes sink-structures and reduces storage capacity (Landhäusser and Lieffers, 2003). The removal of the bark and cambium through stem damage influences the transport capacity between sources and sinks thus hindering the refilling or mobilization of reserves (Högberg et al., 2001; Moore, 2013; Purcell, 2014; Mei et al., 2015). However, stem damage typically allows respiration as water transport is carried out through the xylem.

New growth to restore the functional balance between aboveand below-ground tissues after stress may depend on the amount of carbohydrate reserves in storage pools, as the remobilization of reserves support metabolic functioning during stressful periods and can produce compensatory growth or additional reserve investment facilitating recovery after the stress (Chapin et al., 1990; Dietze et al., 2014; Ramirez et al., 2018). Carbohydrate reserves are mainly comprised of non-structural carbohydrates (NSC) that are formed from low weight sugars and starch (Hoch et al., 2003). Sugars are mobilized easily and used for short-term metabolism, while starch is stored in a more recalcitrant form for long-term use during and after periods of severe stress (Chapin et al., 1990; Dietze et al., 2014; Martínez-Vilalta et al., 2016).

Photoassimilates are allocated to growth or to reserves and other physiological functions such as defense (Chapin et al., 1990; Dietze et al., 2014; Hoch, 2015). Thus, the concentration of NSC in tree tissue depends on the ability of components to use plant-available resources (sink strength), and on the long-distance transport between the carbon sources (either NSC in pools or carbohydrates synthesized by leaves) and carbon sinks (mainly respiratory metabolism, storage of NSC, and tissue growth) (Lacointe, 2000; Minchin and Lacointe, 2005). Therefore, damage that results in tissue loss will affect the carbon allocation priorities. This response will depend both on the functional role of the organs involved and timing of the damage, as different organs may function as carbon sources or carbon sinks at different times (Li et al., 2002).

Concurrent damage can cause urban tree health to decline and, in extreme cases, lead to mortality (Calfapietra et al., 2015). However, the physiological response of trees to a combination of stress-factors is generally unclear (Niinemets and Valladares, 2008; Niinemets, 2010). The interaction of several stress-factors generates a unique response that may be more severe (negative interaction) or less severe (positive interaction) than the sum of their individual effects (Mittler, 2006; Niinemets, 2010). Here, we evaluated the effects of different individual and combined stresses on the dynamics of NSC reserves in tree saplings using a fully-factorial manipulative experiment with three common North American urban tree species (Fraxinus pennsylvanica, Celtis occidentalis, and Tilia cordata). Trees were subjected to increasing levels of commonly occurring urban damage: (1) three levels of defoliation, (2) three levels of root reduction, and (3) two levels of stem damage. These stress treatments were applied individually and in combinations of two or three simultaneously at different intensities. These disturbance treatments offered the potential to act in a complementary way modifying primarily the carbon sources (defoliation), sinks (root reduction), and transport capacity (stem damage). Hence, each treatment created an imbalance between resource production and reserve demand and availability (Farrar and Jones, 2000).

Since plants require a minimum concentration of NSC stored to maintain their basic functioning (McDowell, 2011; Sala et al., 2012; Martínez-Vilalta et al., 2016), we hypothesized that (i) tissue damage will induce larger reductions in growth than in NSC concentrations, and (ii) combinations of stress treatments that minimally alter the "functional equilibrium" (e.g., similar reductions of leaf and root area) will have the least impact on NSC concentrations (although not on tree growth) helping to maintain tree health and integrity.

\section{MATERIALS AND METHODS}

\section{Study Site}

The study was conducted in the municipal nursery of the city of Montreal, province of Quebec, Canada. The site lies at $45^{\circ} 30^{\prime \prime} \mathrm{N}, 73^{\circ} 33^{\prime} \mathrm{W}$ (about $35 \mathrm{~m}$ of elevation). The mean annual precipitation is $978 \mathrm{~mm}(215 \mathrm{~mm}$ snow and $763 \mathrm{~mm}$ rain). The mean annual temperature is $6.2^{\circ} \mathrm{C}$ and the mean annual growing season temperature is $14.4^{\circ} \mathrm{C}$, lasting generally from May to October.

\section{Study Species}

We studied three tree species that are among the most commonly planted trees in the city of Montreal: Celtis occidentalis Linnaeus 
(Common Hackberry; native), Fraxinus pennsylvanica Marsh. (Green ash; native), and Tilia cordata Mill. (little-leaf linden; introduced in America from Europe). These species have growth strategies and growth rates considered as moderate, intermediate and rapid, respectively, which could determine different responses of reserve allocation and growth under stress (Table 1).

\section{Growth Measurements}

The trees were field-grown seedling-propagated in 2003 and 2004 in the Montreal municipal nursery. The average diameter at $40 \mathrm{~cm}$ above the ground and height of the trees at the beginning of the study (July 2012) were 53.5 (7.8) $\mathrm{mm}$ and $3.1(0.6) \mathrm{m}$ for C. occidentalis, $51.8(8.9) \mathrm{mm}$ and $4.4(0.6) \mathrm{m}$ for Fraxinus pennsylvanica, and $63.5(4.7) \mathrm{mm}$ and $4.3(0.3) \mathrm{m}$ for Tilia cordata (standard deviation in brackets). The diameter was measured with a Mitutoyo Digimatic caliper $(0.01 \mathrm{~mm}$ accuracy) at $40 \mathrm{~cm}$ above ground level to avoid actively growing branches. To increase accuracy, diameter was measured along two perpendicular axes at a height marked with a permanent steel nail. Tree height was measured with a TruPulse 360 laser with a resolution of $10 \mathrm{~cm}$ for linear lengths (Laser Technology, Inc., CO, United States). Trunk diameter (at $40 \mathrm{~cm}$ height) and total tree height were measured periodically between July 2012 and May 2015. Diameter was measured approximately every 2 months during the growing season while the height was measured annually. To allow for comparisons between the different tree species, growth measurements were normalized.

\section{Stress Treatments}

At the beginning of the study, trees were assigned randomly to one of 18 treatment combinations (see details below). Treatments were first applied in July 2012 and repeated in July 2013, which corresponded to the month of maximum leaf area. The stress treatments consisted of various gradients of defoliation, root reduction, and stem damage. The total number of trees in the experiment was 267 individuals (116 C. occidentalis, $86 \mathrm{~F}$. pennsylvanica, and $65 \mathrm{~T}$. cordata). Individuals of each species were divided in blocks ensuring at least three trees

TABLE 1 | Functional characteristics of the tree species studied.

\begin{tabular}{|c|c|c|c|}
\hline Species/Trait & $\begin{array}{c}\text { Celtis } \\
\text { occidentalis }\end{array}$ & $\begin{array}{c}\text { Fraxinus } \\
\text { pennsylvanica }\end{array}$ & Tilia cordata \\
\hline Foliar carbon (\%) & 41.0 & 46.5 & 47.0 \\
\hline Foliar nitrogen (\%) & 1.2 & 2.0 & 2.7 \\
\hline Foliar carbon/nitrogen & 33.9 & 23.4 & 18.0 \\
\hline $\begin{array}{l}\text { Specific leaf area } \\
\left(\mathrm{mm}^{2} \mathrm{mg}^{-1}\right)\end{array}$ & 17.3 & 15.2 & 18.6 \\
\hline $\begin{array}{l}\text { Photosynthetic capacity } \\
\left(\mu \mathrm{mol} \mathrm{CO}_{2} \mathrm{~m}^{-2} \mathrm{~s}^{-1}\right)\end{array}$ & 6.0 & 13.7 & 15.3 \\
\hline Wood density $\left(\mathrm{mg} \mathrm{mm}^{-3}\right)$ & 0.7 & 0.6 & 0.4 \\
\hline Growth rate & Moderate & Intermediate & Rapid \\
\hline Shade tolerance* & Intermediate & Intermediate & Tolerant \\
\hline Lifespan & Moderate & Short & Moderate \\
\hline
\end{tabular}

*Data from Niinemets and Valladares (2006). per treatment given the availability of individuals. Thus, three blocks were established in the case of the $T$. cordata, four blocks for F. pennsylvanica and six blocks for C. occidentalis (Supplementary Figure 1).

The experiment was set up as a fully factorial design with three levels of defoliation (DF) [severe (75\%), moderate (37\%) and control $(0 \%)]$, three levels of root reduction (RR) [severe (75\%), moderate (37\%) and control (0\%)], two levels of stem damage (SD) [severe (50\%) and control (0\%)], and all the possible combinations among these three treatments and intensities (Figure 1). The defoliation (DF) treatment consisted of removing leaves manually at the base of the petiole, removing $37 \%$ of leaves per branch in the moderate treatment, and $75 \%$ in the severe treatment (Figure 1). The root reduction (RR) treatment consisted of removing part of the root system outside a $30 \mathrm{~cm}$ radius from the trunk using a tree spade machine (Figure 1). The machine, with independent blades that encircled the tree, cut the roots to a depth of $1.2 \mathrm{~m}$, and removed $37 \%$ in the moderate treatment and $75 \%$ in the severe treatment. The stem damage (SD) treatment consisted of removing a $40 \mathrm{~mm}$ wide band around $50 \%$ of the stem circumference at $30 \mathrm{~cm}$ above the ground using a bark blaster girdling tool that removed both the cambium and phloem (Figure 1).

\section{Analysis of Carbohydrate Concentrations}

In the spring and autumn of 2014, we measured the concentrations of NSC (low weight sugars plus starch) in roots, stems, and branches of all 267 tree saplings. These measurements took place the growing season after the stress treatments were applied in July 2013 to monitor tree reaction in terms of growth reallocation and reserve utilization. The concentrations of NSC in leaves were only measured in the summer of 2014. Stem samples were taken with a $4.3 \mathrm{~mm}$ diameter increment borer at $130 \mathrm{~cm}$ from the ground for each individual. Root samples were taken with a $4.3 \mathrm{~mm}$ increment borer from large surface roots within $10 \mathrm{~cm}$ of the base of the stem. Stem and root samples were comprised of phloem and xylem from all growth rings including the pith but not the outer bark. Top branches were cut with a tree trimmer so that the twenty leaves per tree were sampled from the entire canopy. Collected samples were placed in paper bags and refrigerated right after collection. Within $8 \mathrm{~h}$ of collection samples were microwaved in the lab to stop enzymatic activity (Popp et al., 1996), oven dried, and ground using a ball mill. Samples were analyzed for NSC concentration following the standard methods proposed by Hoch et al. (2002). Ground plant material was dissolved for $30 \mathrm{~min}$ in distilled water. Starch was broken down into glucose, and sucrose into glucose and fructose with clarase (Aspergillus oryzae, Enzyme Solutions Pty Ltd., Croydon South, VIC, Australia) incubation at $40^{\circ} \mathrm{C}$ for $15 \mathrm{~h}$. Phosphoglucose-isomerase was added to the solution. The total amount of glucose, which corresponded to total NSC, was quantified photometrically in a microplate photometer at $340 \mathrm{~nm}$ (Thermo Fisher Scientific, Waltham, MA, United States) after the conversion of glucose to gluconate-6-phosphate (hexokinase; Sigma-Aldrich, St. Louis, MO, United States). Subsequently, an aliquot of the original extract was treated with invertase and phosphoglucose-isomerase (both Sigma-Aldrich) to determine 


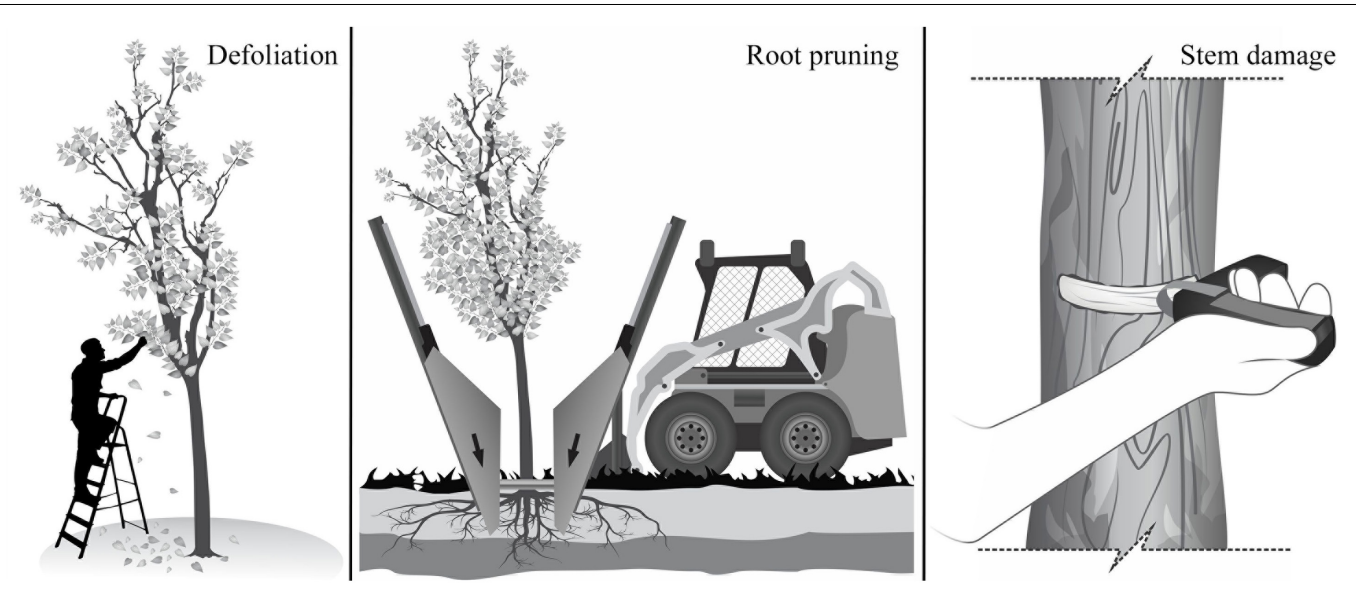

FIGURE 1 | Schematic representation of the stress treatments applied to trees of F. pennsylvanica, C. occidentalis, and T. cordata: defoliation, root reduction, and stem damage.

the amount of glucose, fructose, and sucrose with a glucose test (see above). Starch was calculated as NSC minus soluble sugars (soluble sugars $=$ sucrose + fructose + glucose) . Pure starch and glucose, fructose, and sucrose solutions were used as standards. Plant powder from peach leaves (Leco, St. Joseph, MI, United States) was included to control the replicability of the extractions. NSC concentrations are reported as percentage of dry matter.

\section{Statistical Analysis}

To avoid autocorrelation of errors produced by continuous measures of diameter and height, and reserve concentrations (soluble sugars, starch, and NSC), linear mixed-effect models were used to evaluate the effect of the stress treatments (DF, $\mathrm{RR}$, and $\mathrm{SD}$ ) and their interactions on growth and reserve concentrations in the different tissues (leaves, roots, stems, and branches) per species (Gregoire, 1987). Blocks were used as random effect (Supplementary Figure 1). Model calculations were performed using the R package "Ime4" (Bates et al., 2014). The function difflsmeans in the "ImerTest" package (Kuznetsova et al., 2016) was used as a post hoc test to determine differences in the least square means among treatment combinations. The relationship between concentration of reserves and growth was assessed through the coefficient of determination (Pearson's $r$ ). All statistical analyses were performed with the software R (R Foundation for Statistical Computing, Vienna, Austria).

\section{RESULTS}

\section{Effects of Stress on Tree Growth}

No mortality was recorded during the study period. All treatments had a negative impact on both diameter and height normalized growth for all species, except for stem damage in $F$. pennsylvanica that caused a significant increase in diameter growth (Figure 2, Supplementary Figures 2, 3, and Supplementary Table 1). In most of the stress cases, only severe stress had a significant effect on the normalized growth (75\% DF or 75\% RR), except for C. occidentalis and T. cordata where there was already a significant effect at low root reduction intensities. Stem damage only significantly affected the diameter growth of F. pennsylvanica. Interactions seemed mostly nonsignificant. Only the interaction between defoliation and root reduction (DF:RR) reduced diameter growth of C. occidentalis and the interaction between defoliation and stem damage (DF:SD) reduced height growth on F. pennsylvanica (Figure 2, Supplementary Figures 2, 3, and Supplementary Table 1).

\section{Effects of Single Stress Treatments on NSC Concentrations}

In spring 2014, the first measurements of NSC in woody tissues showed concentrations between 0.4 and $12.0 \%$ and at the second assessment in fall 2014 concentrations varied between 1.1 and $11.7 \%$, depending on tissues, species, and treatments (Supplementary Figures 4, 5). Concentrations of NSC in leaves measured in summer 2014 varied between 3.3 and $12.7 \%$, with highest concentrations in the control trees of C. occidentalis and lowest in F. pennsylvanica (Supplementary Figure 6). Reserve concentrations were in most cases not significantly affected by single treatments in neither spring nor autumn measurements (Figure 3 and Supplementary Table 2). When the effects were significant, high intensity treatments tended to significantly increase reserve concentrations in stems and roots in both periods, but reduced their concentration in branches (Figure 3). Single treatments of root reduction and stem damage significantly decreased the NSC concentrations in leaves of C. occidentalis only (Figure 3 and Supplementary Table 2).

\section{Effects of Combined Stress Treatments on NSC Concentrations}

The number of significant interactions between stress treatments and reserve concentrations was extremely low (Figure 5 and Supplementary Table 2). In spring 2014, severe defoliation and stem damage interactions were significant and increased 


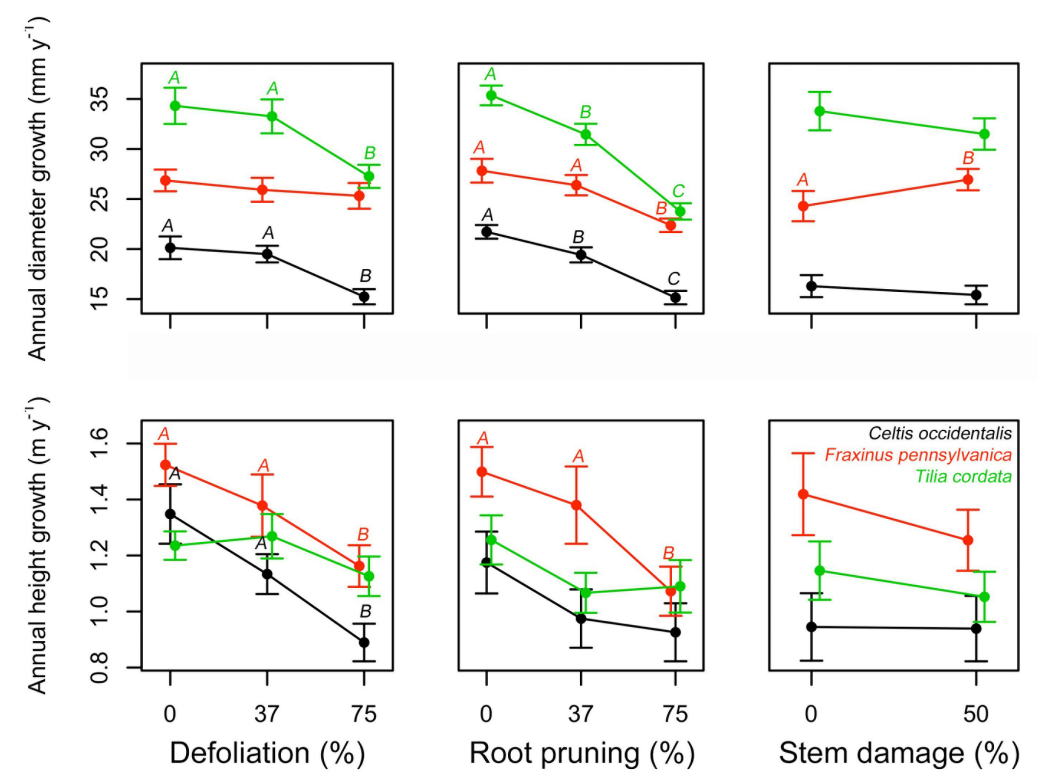

FIGURE 2 | Single effects of a gradient of defoliation, root reduction, and stem damage on diameter and height growth of Celtis occidentalis, Fraxinus

pennsylvanica, and Tilia cordata. Error bars represent the standard error of the mean. Different letters represent significant mean differences between stress levels.
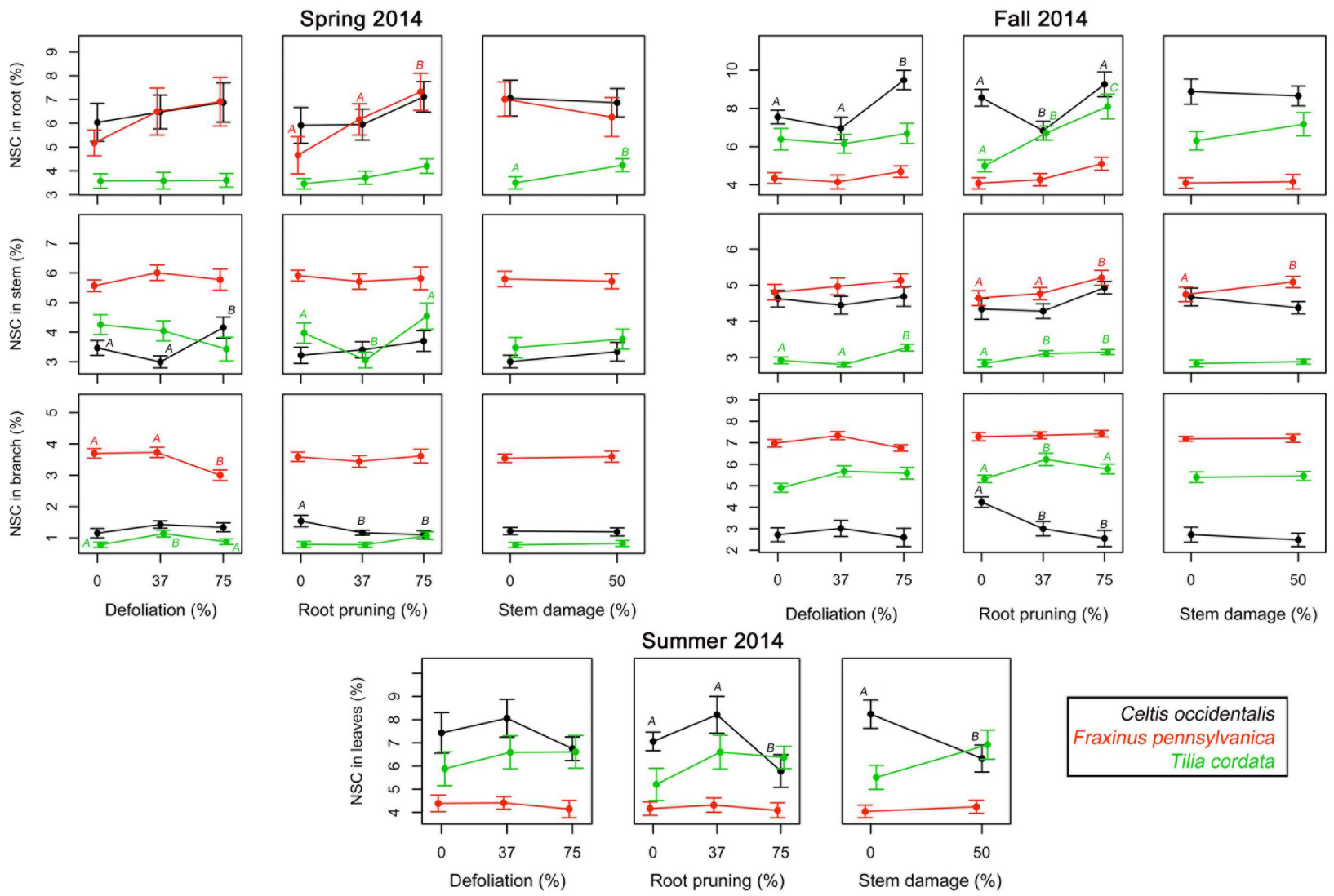

Summer 2014
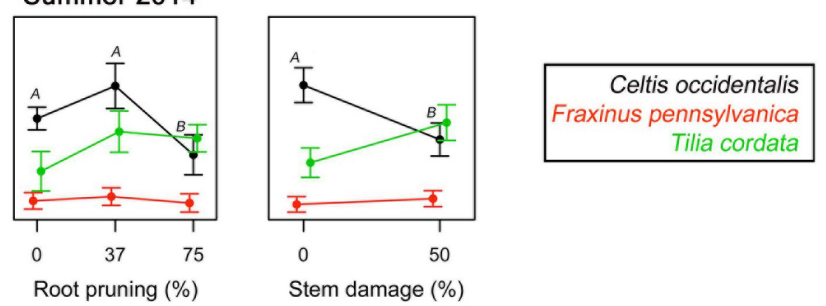

FIGURE 3 | Single effects of a gradient of defoliation, root reduction, and stem damage on non-structural carbohydrates (NSC) concentrations in tissues of Celtis occidentalis, Fraxinus pennsylvanica, and Tilia cordata in the spring, summer and fall of 2014. Error bars represent the standard error of the mean. Different letters represent significant mean differences between stress levels. 
NSC concentrations in C. occidentalis stems. In Fraxinus pennsylvanica, moderate defoliation (37\%) along with an increase in stem damage decreased NSC concentrations in roots of F. pennsylvanica relative to severe defoliation (75\%) with stem damage. In fall 2014, severe root reduction and stem damage had a significant effect and reduced NSC concentrations in roots. The interaction of root reduction and stem damage had a significant negative effect on NSC concentrations in leaves in summer 2014 in both $C$. occidentalis and F. pennsylvanica. For T. cordata no significant interactions were found.

\section{Relationship Between NSC Concentrations and Tree Growth}

Higher NSC concentrations were consistently associated with lower diameter increments for all three species (Figure 5). Specifically, we found significant negative correlations between diameter increment and NSC concentrations in roots and stems of C. occidentalis, roots of F. pennsylvanica, and roots, and stems and branches of $T$. cordata. On the contrary, we did not find any significant correlation between height increment and NSC concentrations in any tissues of the three species for both treatment periods (data not shown).

\section{DISCUSSION}

Assessing the impact of different levels of defoliation, root reduction, and stem damage separately and in combinations, we observed a consistent decline in tree diameter and height growth with increasing stress intensity; the sole exception was the positive effect on diameter growth of $F$. pennsylvanica following stem damage (Figure 2 and Supplementary Table 1). However, the impacts of different levels of defoliation, root reduction and stem damage on carbohydrate reserves were (1) less consistent, (2) did not follow a simple linear trend with increasing stress intensities, (3) were relatively mild, and (4) changed with each organ, species and combination of treatments. We found some significant interactions among the different stress treatments that make any interpretation of single effects difficult. Nonetheless, in cases where some effects were observed, single stress treatments induced an increase in reserve concentrations in stem and roots, and a decrease in branches. On the contrary, combined stress treatment effects on reserve concentrations were more variable both among species and the tree organs evaluated.

\section{Effects of Single Stress Treatments on Tree Growth and Reserve Concentrations}

As hypothesized, both diameter and height growth were negatively affected by the increasing level of stress intensity inflicted on the trees (Figure 2 and Supplementary Table 1). At the end of the study, differences in growth between control and the most affected trees were between 13 and 19\% for diameter and between 9 and 16\% for height (Supplementary Figure 2). Although the growth responses to stress treatments are complex and depend on the species and type of stress applied, our results are quantitatively similar to the growth reduction reported for defoliation and root reduction treatments in other studies (Quentin et al., 2011; Jacquet et al., 2012; Wiley, 2013; Dong et al., 2016). This reduction in growth can be explained by the lower carbon uptake due to defoliation, and lower water and nutrient uptake due to root reduction. Interestingly, although we expected stem damage to induce a decrease in tree growth due to the disruption of the transport system and consequent reduction of photosynthate movement to the roots (Regier et al., 2010; Mei et al., 2015), we instead found a significant increase in tree diameter for F. pennsylvanica. The stem damage applied to the trees was relatively mild as it only affected $50 \%$ of the circumference. It has been reported that most coniferous species are able to resist up to $25 \%$ basal girdling (Filip et al., 2007) while some broadleaf species are able to resist more than $50 \%$ girdling (Holmes, 1984; Moore, 2013) or even 100\% girdling damage such as in white poplar (Glass, 2011). The increase presented in tree diameter of $F$. pennsylvanica may be due to an accumulation of carbohydrates above the wound zone (Moore, 2013) in reaction to the injury as shown in Vitali et al. (2019).

Most of the single defoliation stress treatments did not lead to a significant reduction in the concentrations of NSC in the different tree tissues (Figure 3). In most cases, root reduction caused an increase in the NSC concentrations in the stem as well as the roots. However, in C. occidentalis there was a reduction in the NSC concentrations in branches, especially after root reduction. Reduction of carbohydrate reserves in tree organs has been shown to occur in the weeks following stress caused by defoliation (Palacio et al., 2012; Wiley et al., 2013; Atkinson et al., 2014), and stem girdling, especially in the tissues that mobilize reserves to maintain physiological activity (Mei et al., 2015). Nevertheless, a higher concentration of carbohydrates in stems and roots for all three tree species 9 months after the stress treatments in our study may indicate a fast recovery for tree species following injuries to below- and above-ground tree organs, probably indicating a good resilience of these tree species to these types of injuries.

The increase in carbohydrate reserve concentrations in stems and roots after carbon-limiting conditions may indicate that the stem and roots are secure places to store carbohydrates, and thus they can maintain the availability of resources for resprouting or re-foliation after stress or under possible further stress episodes (Gibon et al., 2009; Wiley, 2013). This carbohydrate increase in these tissues may have been reached through compensatory mechanisms, such as increasing nitrogen concentrations and photosynthetic rates in the remaining foliage after defoliation (Pinkard and Beadle, 1998; Vanderklein and Reich, 1999; Handa et al., 2005; Eyles et al., 2009). Nevertheless, although it is expected that an increase in nitrogen concentrations and photosynthetic rates leads to an increase in carbohydrate concentrations ( $\mathrm{Li}$ et al., 2016), unlike woody tissues, only a few stress treatments had a significant effect on reserve concentrations in leaves, and those that had a significant effect caused a reduction in the carbohydrate reserves (Figure 4), which suggests no evidence of photosynthetic up-regulation and compensatory responses. 


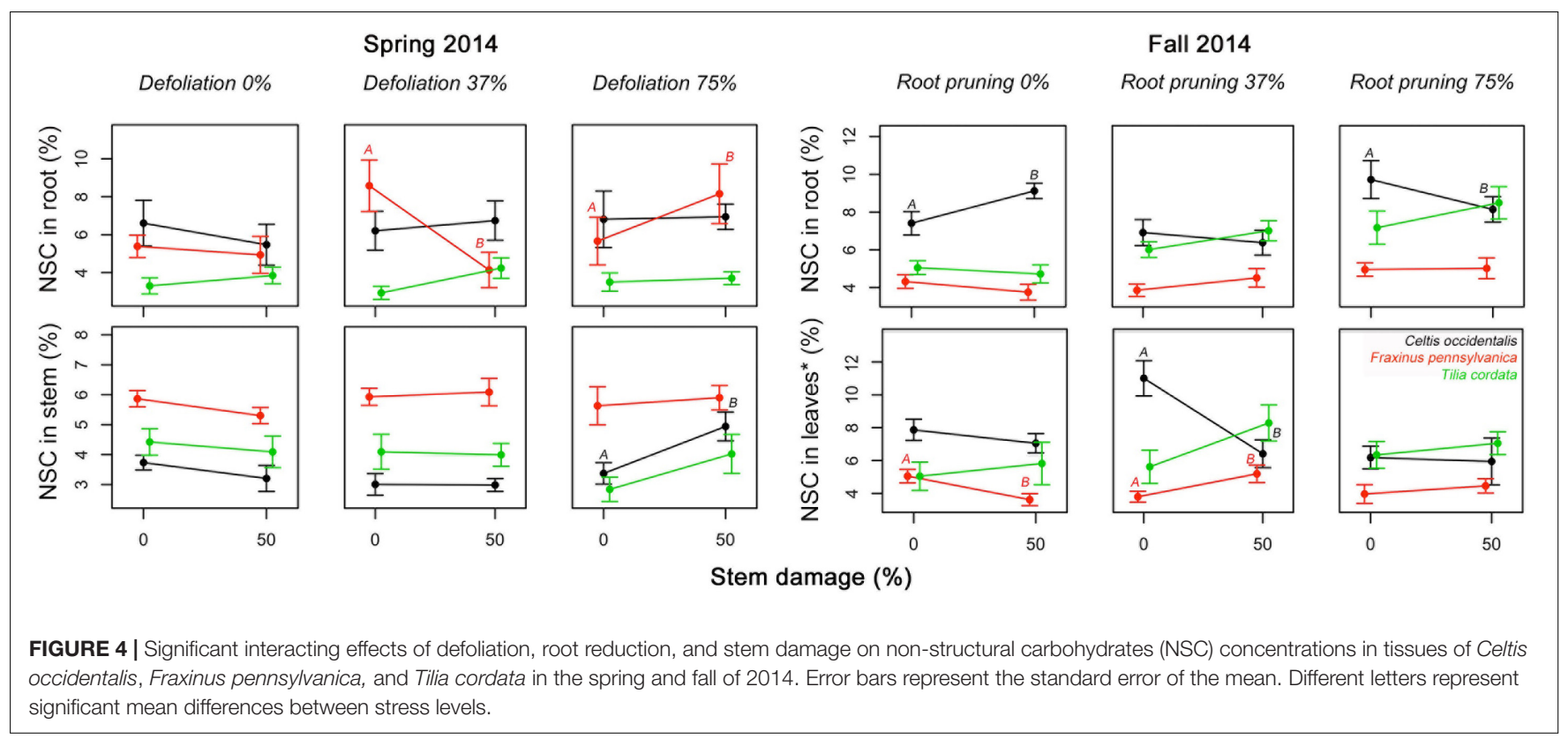

\section{Effects of Multiple Stress Treatments on Tree Growth and Reserve Concentrations}

We hypothesized that combinations of stress treatments that alter the "functional equilibrium" the least (e.g., similar reductions of leaf and root area) would have the least impact on NSC concentrations; however, we did not find a consistent response. We expected a positive interaction in reserve concentrations in treatments that involved a combination of defoliation and root reduction compared to single stress treatments. Yet, none of the interactions between DF and RR on reserves were significant (Figure 4 and Supplementary Table 2). We also expected that a combination of tissue loss (by either defoliation or root reduction) and stem damage would lead to a negative interaction (reduction of reserves concentration) because stem damage limits the supply of reserves either to leaves (from roots) or to roots (from new photosynthates). We did find several significant interactions between tissue loss and stem damage but with different patterns. We found that severe defoliation (75\%) with stem damage (50\%) increased reserve concentrations in roots and stems of $F$. pennsylvanica and C. occidentalis, respectively (Figure 4). As suggested above, this may indicate the mobilization of reserves to more secure tissues under severe stress conditions (Gibon et al., 2009; Wiley et al., 2013). However, moderate defoliation (37\%) with stem damage $(50 \%)$ reduced reserve concentrations in roots in $F$. pennsylvanica. Severe root reduction $(75 \%)$ and stem damage (50\%) also caused a reduction in reserve concentrations in roots of C. occidentalis, which may indicate that stem damage is limiting the supply of reserves from leaves to roots and thus, roots are spending their reserves in metabolism and/or increasing root production to compensate for root loss and exploit new available soil nutrients and water resources (Mei et al., 2015). Moderate root reduction (37\%) and stem damage $(50 \%)$ caused a contrasting effect in reserve concentrations in leaves of $C$. occidentalis and F. pennsylvanica (Figure 5), decreasing NSC in C. occidentalis and increasing reserves in F. pennsylvanica. A decrease in reserve concentrations after stress treatments in C. occidentalis may indicate the lack of compensatory photosynthesis reactions to recover carbon supply (McNaughton, 1983). A reduction in the carbon supply through photosynthesis may lead to a fast depletion of the reserve pools, thus increasing the stress effect on the trees (Niinemets, 2010).

It should be noted that treatments were applied in summer 2012 and 2013, while the NSC concentration measurements were performed the next growing season in spring and autumn of 2014 for woody tissues and in summer for leaves. Sampled leaves were less than 1 year old, branches were generally from the current year and stems and roots were up to several years old. Thus, stem and roots sampled combine pre-treatment, treatment and post-treatment tissues. Since NSC reserves stored in stems and roots serve as a long-term reservoir for responding to high impact damage (Clark and Clark, 1991; Poorter et al., 2010; Clarke et al., 2013) and stay stable over time (Hartmann and Trumbore, 2016), this may be a possible explanation for the lack of a consistent relationship between stress treatments and NSC concentrations in woody tissues. Also, since many models were fitted simultaneously, some of the interactive effects may be spurious due to multiple testing.

\section{Relationship Between Carbohydrate Reserves and Tree Growth}

We found a negative relationship between NSC concentrations and diameter increment suggesting an overall conservative strategy to cope with maintenance respiration, tissue reconstruction or new tissue production following some form of stress (Körner, 2003, 2015; Muller et al., 2011; Figure 5). This relationship was significant in the three woody tissues of T. cordata and persistent in roots of all three tree species. This 

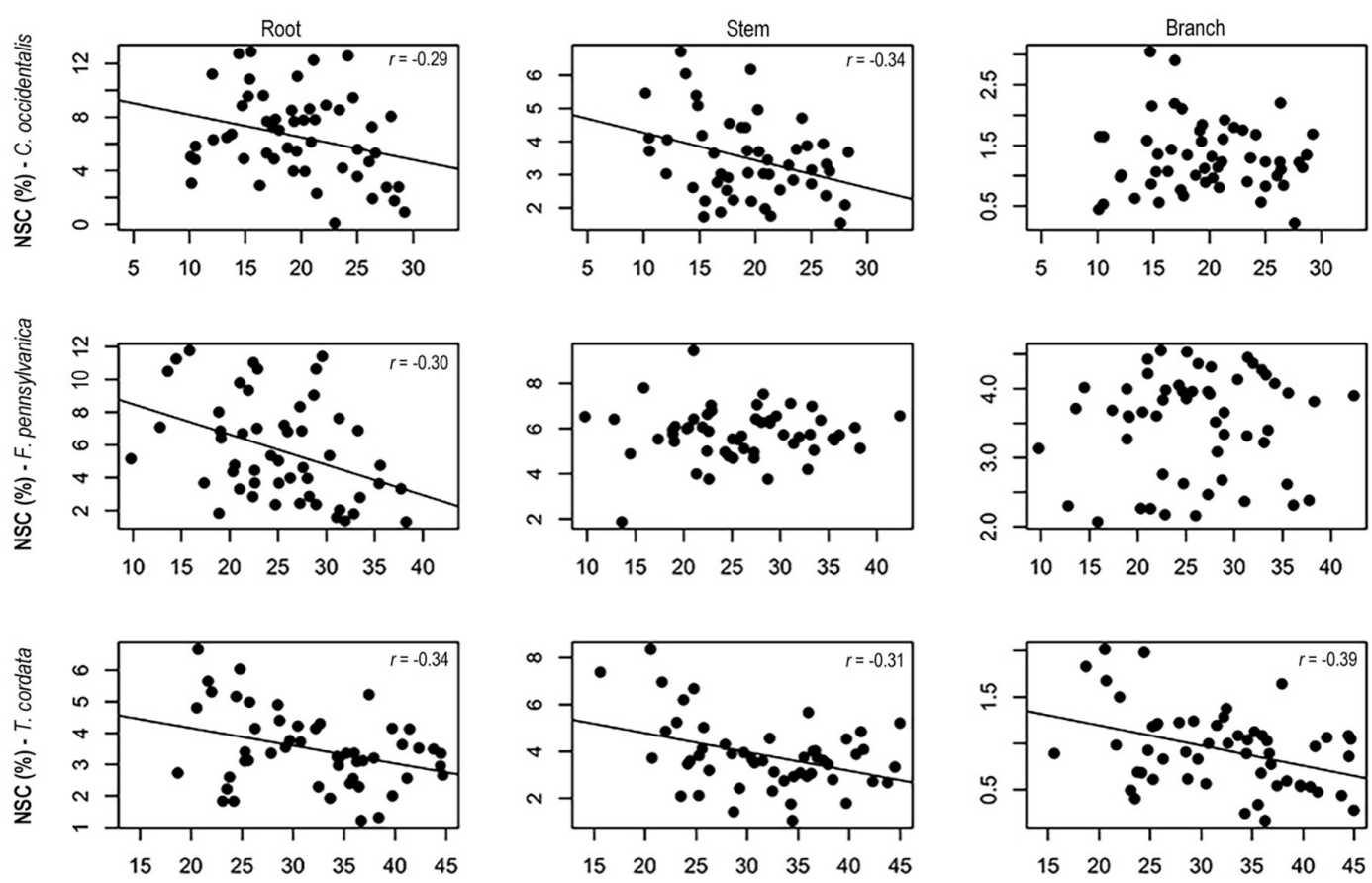

Diameter increment $\left(\mathrm{mm}\right.$ year $\left.{ }^{-1}\right)$

FIGURE 5 | Relationships between non-structural carbohydrates concentrations in spring 2014 and diameter increment in Celtis occidentalis, Fraxinus pennsylvanica, and Tilia cordata. Model lines represent significant relationships between non-structural carbohydrates (NSC) concentrations and diameter increment.

may indicate that trees of T. cordata showed higher response to stress than the other two species. Although T. cordata is a shade tolerant species, it presents characteristics of fast-growing species such as high foliar nitrogen, photosynthetic capacity, and lower wood density (Table 1). This may indicate a lower allocation of carbon to defense traits and thus a higher dependence on reserves than the other species to maintain a positive carbon balance. These results support the idea that under stress conditions, fast-growing species respond with higher flexibility than slow-growing species (Atkinson et al., 2014).

Our results suggest that following a disturbance to some part of the tree, trees may mobilize accumulated stored NSC over the short term to repair the damage and increase growth, but over the medium to long term the strategy seems to replenish the reserve pool as quickly as possible to the detriment of tree growth. Increasing reserves under the conditions of lower carbon uptake imposed by the stress treatments is consistent with previous studies suggesting that allocation of carbon to reserves is an active process that does not depend on the balance between carbon supply and demand for growth and metabolism; trees regulate the levels of reserves at the expense of growth (Chapin et al., 1990; Silpi et al., 2007; Sala et al., 2012; Wiley and Helliker, 2012). Such behavior in carbohydrate reserves suggests that trees adjust their level of reserves to meet the new metabolic demands (Silpi et al., 2007) because survival under stress conditions may require a higher availability of carbon for maintaining physiological functions, such as metabolism, hydraulic integrity and osmotic exchange of the soluble sugars, instead of maintaining growth
(Sala et al., 2012; Wiley and Helliker, 2012). This behavior may be even more marked at increased age (with higher biomass accumulation) and thus, the effect of age should be considered for future analyses since urban forests are mainly composed by mature trees.

\section{CONCLUSION}

This study examined the single and combined effects of three frequent urban stresses (defoliation, root reduction, and stem damage) on the growth and NSC reserve concentrations in young trees of three common species under field conditions. Our results showed a consistent inverse relationship between diameter growth and total NSC reserve in all three tree species, indicating that trees prioritize reserve accumulation over growth following injuries. Globally, trees tended to accumulate NSC in roots and stems rather than branches 9-12 months following various combinations of stresses. Significant interactions were found between the three stresses applied, indicating that some combinations of stresses while not showing simple additive effects, could modify tree responses. Thus, moderate and mild stress caused by defoliation, root reduction and girdling events do not generally adversely affect plant physiology in terms of growth and reserves. However, trees under severe stress, especially under conditions that alter the functional equilibrium, may drastically reduce their growth rates and, depending on the severity, could eventually die with large amounts of NSC stored in their tissues. 


\section{DATA AVAILABILITY STATEMENT}

The raw data supporting the conclusions of this article will be made available by the authors, without undue reservation.

\section{AUTHOR CONTRIBUTIONS}

JR, IH, and CM contributed to the design of the research. JR carried out the fieldwork. JR performed laboratory analysis with the support CM and IH. JR, VV, and JM-V wrote the manuscript in collaboration with all co-authors. All authors contributed to the article and approved the submitted version.

\section{FUNDING}

This research was supported by the NSERC/HydroQuebec research chair on tree growth control, a Canadian

\section{REFERENCES}

Atkinson, R. R. L., Burrell, M. M., Rose, K. E., Osborne, C. P., and Rees, M. (2014). The dynamics of recovery and growth: how defoliation affects stored resources. Proc. R. Soc. B 281:20133355. doi: 10.1098/rspb.2013.3355

Bates, D., Maechler, M., Bolker, B., and Walker, S. (2014). Lme4: Linear MixedEffects Models Using Eigen and s4 R Package Version 11-7.

Calfapietra, C., Peñuelas, J., and Niinemets, Ü (2015). Urban plant physiology: adaptation-mitigation strategies under permanent stress. Trends Plant Sci. 20, 72-75. doi: 10.1016/j.tplants.2014.11.001

Chapin, F. S., Schulze, E. D., and Mooney, H. A. (1990). The ecology and economics of storage in plants. Annu. Rev. Ecol. Syst. 21, 423-447. doi: 10.1146/annurev. es.21.110190.002231

Clark, D. B., and Clark, D. A. (1991). The impact of physical damage on canopy tree regeneration in tropical rain forest. J. Ecol. 79, 447-457. doi: 10.2307/2260725

Clarke, P. J., Lawes, M. J., Midgley, J. J., Lamont, B. B., Ojeda, F., Burrows, G. E., et al. (2013). Resprouting as a key functional trait: how buds, protection and resources drive persistence after fire. New Phytol. 197, 19-35. doi: 10.1111/nph. 12001

Deslauriers, A., Caron, L., and Rossi, S. (2015). Carbon allocation during defoliation: testing a defense-growth trade-off in balsam fir. Front. Plant Sci. 6:338. doi: 10.3389/fpls.2015.00338

Dietze, M. C., Sala, A., Carbone, M. S., Czimczik, C. I., Mantooth, J. A., Richardson, A. D., et al. (2014). Nonstructural carbon in woody plants. Annu Rev. Plant Biol. $65,667-687$.

Dong, T., Duan, B., Korpelainen, H., Niinemets, Ü, and Li, C. (2019). Asymmetric pruning reveals how organ connectivity alters the functional balance between leaves and roots of Chinese fir. J. Exp. Bot. 70, 1941-1953. doi: 10.1093/jxb/ erz013

Dong, T., Duan, B., Zhang, S., Korpelainen, H., Niinemets, Ü, and Li, C. (2016). Growth, biomass allocation and photosynthetic responses are related to intensity of root severance and soil moisture conditions in the plantation tree Cunninghamia lanceolata. Tree Physiol. 36, 807-817. doi: 10.1093/treephys/ tpw025

Eyles, A., Pinkard, E. A., and Mohammed, C. (2009). Shifts in biomass and resource allocation patterns following defoliation in Eucalyptus globulus growing with varying water and nutrient supplies. Tree Physiol. 29, 753-764. doi: 10.1093/ treephys/tpp014

Farrar, J. F., and Jones, D. L. (2000). The control of carbon acquisition by roots. New Phytol. 147, 43-53. doi: 10.1046/j.1469-8137.2000.00688.x

Filip, G. M., Schmitt, C. L., Scott, D. W., and Fitzgerald, S. A. (2007). Understanding and defining mortality in western conifer forests. West. J. Appl. For. 22, 105-115. doi: 10.1093/wjaf/22.2.105
Foundation for Innovation infrastructure grant and by a scholarship from the Quebec research funds for nature and technology.

\section{ACKNOWLEDGMENTS}

We would like to thank David Andres Herrera, Sergio Martinez, and Mathieu Messier for their fieldwork support. We would also like to thank Martin Gaudet from the Montreal municipal nursery for logistical support.

\section{SUPPLEMENTARY MATERIAL}

The Supplementary Material for this article can be found online at: https://www.frontiersin.org/articles/10.3389/fpls.2021. 715399/full\#supplementary-material

Gibon, Y., Pyl, E., Sulpice, R., Lunn, J. E., Höhne, M., Günther, M., et al. (2009). Adjustment of growth, starch turnover, protein content and central metabolism to a decrease of the carbon supply when Arabidopsis is grown in very short photoperiods. Plant Cell Environ. 32, 859-874. doi: 10.1111/j.1365-3040.2009. 01965.x

Glass, W. (2011). Vegetation Management Guideline. White Poplar (Populus alba L). Chicago, IL: Illinois Natural History Survey, Prairie Research Institute, University of Illinois.

Gregoire, T. G. (1987). Generalized error structure for forestry yield models. For. Sci. 33, 423-444.

Handa, T., Körner, C., and Hättenschwiler, S. (2005). A test of the treeline carbon limitation hypothesis by in situ CO2 enrichment and defoliation. Ecology 86, 1288-1300. doi: 10.1890/04-0711

Hartmann, H., and Trumbore, S. (2016). Understanding the roles of nonstructural carbohydrates in forest trees - from what we can measure to what we want to know. New Phytol. 211, 386-403. doi: 10.1111/nph.13955

Hoch, G. (2015). "Carbon reserves as indicators for carbon limitation in trees," in Progress in Botany, Vol. 76, eds U. Lüttge, and W. Beyschlag (Cham: Springer International Publishing).

Hoch, G., Popp, M., and Körner, C. (2002). Altitudinal increase of mobile carbon pools in Pinus cembra suggests sink limitation of growth at the Swiss treeline. Oikos 98, 361-374. doi: 10.1034/j.1600-0706.2002.980301.x

Hoch, G., Richter, A., and Körner, C. (2003). Non-structural carbon compounds in temperate forest trees. Plant Cell Environ. 26, 1067-1081. doi: 10.1046/j.00168025.2003.01032.x

Högberg, P., Nordgren, A., Buchmann, N., Taylor, A. F., Ekblad, A., Högberg, M. N., et al. (2001). Large-scale forest girdling shows that current photosynthesis drives soil respiration. Nature 411, 789-792. doi: 10.1038/ 35081058

Holmes, F. (1984). Effects on maples of prolonged exposure by artificial girdling roots. J. Arboric. 10, 40-44.

Jacquet, J. S., Orazio, C., and Jactel, H. (2012). Defoliation by processionary moth significantly reduces tree growth: a quantitative review. Ann. For. Sci. 69, 857-866. doi: 10.1007/s13595-012-0209-0

Konijnendijk, C. C., Kjell, N., Thomas, B. R., and Schipperijn, J. (2005). Urban Forests and Trees. Berlin: Springer-Verlag.

Konijnendijk, C. C., and Randrup, T. B. (2004). "Urban forestry," in Encyclopedia of Forest Sciences, eds J. Burley, J. Evans, and J. Youngquist (Amsterdam: Academic Press).

Körner, C. (2003). Carbon limitation in trees. J. Ecol. 91, 4-17. doi: 10.1046/j.13652745.2003.00742.x

Körner, C. (2015). Paradigm shift in plant growth control. Curr. Opin. Plant Biol. 25, 107-114. doi: 10.1016/j.pbi.2015.05.003 
Kuznetsova, A., Brockhoff, P. B., and Christensen, R. H. B. (2016). Lmertest: Tests in Linear Mixed Effects Models. R Package Version 2.0-30.

Lacointe, A. (2000). Carbon allocation among tree organs: a review of basic processes and representation in functional-structural tree models. Ann. For. Sci. 57, 521-533. doi: 10.1051/forest:2000139

Landhäusser, S. M., and Lieffers, V. J. (2003). Seasonal changes in carbohydrate reserves in mature northern Populus tremuloides clones. Trees 17, 471-476. doi: 10.1007/s00468-003-0263-1

Li, M., Hoch, G., and Körner, C. (2002). Source/sink removal affects mobile carbohydrates in Pinus cembra at the Swiss treeline. Trees 16, 331-337. doi: 10.1007/s00468-002-0172-8

Li, N., He, N., Yu, G., Wang, Q., and Sun, J. (2016). Leaf non-structural carbohydrates regulated by plant functional groups and climate: evidences from a tropical to cold-temperate forest transect. Ecol. Indic. 62, 22-31. doi: 10.1016/ j.ecolind.2015.11.017

Martínez-Vilalta, J., Sala, A., Asensio, D., Galiano, L., Hoch, G., Palacio, S., et al. (2016). Dynamics of non-structural carbohydrates in terrestrial plants: a global synthesis. Ecol. Monogr. 86, 495-516. doi: 10.1002/ecm.1231

McDowell, N. G. (2011). Mechanisms linking drought, hydraulics, carbon metabolism, and vegetation mortality. Plant Physiol. 155, 1051-1059. doi: 10.1104/pp.110.170704

McNaughton, S. J. (1983). Compensatory plant growth as a response to herbivory. Oikos 40, 329-336. doi: 10.2307/3544305

Mei, L., Xiong, Y., Gu, J., Wang, Z., and Guo, D. (2015). Whole-tree dynamics of non-structural carbohydrate and nitrogen pools across different seasons and in response to girdling in two temperate trees. Oecologia 177, 333-344. doi: 10.1007/s00442-014-3186-1

Minchin, P. E. H., and Lacointe, A. (2005). New understanding on phloem physiology and possible consequences for modelling long-distance carbon transport. New Phytol. 166, 771-779. doi: 10.1111/j.1469-8137.2005.01323.x

Mittler, R. (2006). Abiotic stress, the field environment and stress combination. Trends Plant Sci. 11, 15-19. doi: 10.1016/j.tplants.2005.11.002

Moore, G. M. (2013). "Ring-barking and girdling: how much vascular connection do you need between roots and crown?," in Proceedings of the 14th National Tree Symposium 2013, (Adelaide, SA: University of Adelaide).

Muller, B., Pantin, F., Génard, M., Turc, O., Freixes, S., Piques, M., et al. (2011). Water deficits uncouple growth from photosynthesis, increase C content, and modify the relationships between $\mathrm{c}$ and growth in sink organs. J. Exp. Bot. 62, 1715-1729. doi: $10.1093 /$ jxb/erq438

Niinemets, Ü (2010). Responses of forest trees to single and multiple environmental stresses from seedlings to mature plants: past stress history, stress interactions, tolerance and acclimation. For. Ecol. Manag. 260, 16231639. doi: 10.1016/j.foreco.2010.07.054

Niinemets, $\ddot{U}$, and Valladares, F. (2006). Tolerance to shade, drought, and watterlogging of temperate northern hemisphere trees and shrubs. Ecol. Monogr. 76, 521-547. doi: 10.1890/0012-9615(2006)076[0521:ttsdaw]2.0.co;2

Niinemets, Ü, and Valladares, F. (2008). "Environmental tolerance," in Encyclopedia of Ecology, eds J. Sven Erik, and D. F. Brian (Oxford: Elsevier).

North, E. A., D’Amato, A. W., Russell, M. B., and Johnson, G. R. (2017). The influence of sidewalk replacement on urban street tree growth. Urban For. Urban Green. 24, 116-124. doi: 10.1016/j.ufug.2017.03.029

Palacio, S., Hernández, R., Maestro-Martínez, M., and Camarero, J. J. (2012). Fast replenishment of initial carbon stores after defoliation by the pine processionary moth and its relationship to the re-growth ability of trees. Trees 26, 1627-1640. doi: 10.1007/s00468-012-0739-y

Pinkard, E. A., and Beadle, C. L. (1998). Regulation of photosynthesis in Eucalyptus nitens (Deane and Maiden) maiden following green pruning. Trees 12, 366-376. doi: $10.1007 / \mathrm{pl} 100009722$

Poorter, L., Kitajima, K., Mercado, P., Chubiña, J., Melgar, I., and Prins, H. H. T. (2010). Resprouting as a persistence strategy of tropical forest trees: relations with carbohydrate storage and shade tolerance. Ecology 91, 2613-2627. doi: $10.1890 / 09-0862.1$

Popp, M., Wolfgang, L., Andreas, J. M., Richter, A., Schiller, P., and Schwitte, H. (1996). Sample preservation for determination of organic compounds: microwave versus freeze-drying. J. Exp. Bot. 47, 1469-1473. doi: 10.1093/jxb/ 47.10.1469

Purcell, L. (2014). Mechanical Damage to Trees: Mowing and Maintenance Equipment (FNR-492-W). West Lafayette, IN: Purdue University, Forestry and Natural Resources.
Quentin, A. G., Beadlea, C. L., O'Gradya, A. P., and Pinkard, E. A. (2011). Effects of partial defoliation on closed canopy Eucalyptus globulus Labilladière: growth, biomass allocation and carbohydrates. For. Ecol. Manag. 261, 695-702. doi: 10.1016/j.foreco.2010.11.028

Quentin, A. G., O'Grady, A. P., Beadle, C. L., Mohammed, C., and Pinkard, E. A. (2012). Interactive effects of water supply and defoliation on photosynthesis, plant water status and growth of Eucalyptus globulus Labill. Tree Physiol. 32, 958-967. doi: 10.1093/treephys/tps066

Ramirez, J. A., Handa, I. T., Posada, J. M., Delagrange, S., and Messier, C. (2018). Carbohydrate dynamics in roots, stems, and branches after maintenance pruning in two common urban tree species of North America. Urban For. Urban Green. 30, 24-31. doi: 10.1016/j.ufug.2018.01.013

Regier, N., Streb, S., Zeeman, S. C., and Frey, B. (2010). Seasonal changes in starch and sugar content of poplar (Populus deltoides $\times$ nigra cv. Dorskamp) and the impact of stem girdling on carbohydrate allocation to roots. Tree Physiol. 30, 979-987. doi: 10.1093/treephys/tpq047

Sala, A., Woodruff, D. R., and Meinzer, F. (2012). Carbon dynamics in trees: feast or famine? Tree Physiol. 32, 764-775. doi: 10.1093/treephys/tpr143

Sieghardt, M., Erich, M.-R., Elena, P., Couenberg, E., Dimitrakopoulus, A., Rego, F., et al. (2005). "The abiotic urban environment: impact of urban growing conditions on urban vegetation," in Urban Forests and Trees A Reference Book, eds K. Cecil, N. Kjell, R. Thomas, and J. Schipperijn (Berlin: Springer Verlag).

Silpi, U., Lacointe, A., Kasempsap, P., Thanysawanyangkura, S., Chantuma, P., Gohet, E., et al. (2007). Carbohydrate reserves as a competing sink: evidence from tapping rubber trees. Tree Physiol. 27, 881-889. doi: 10.1093/treephys/27. 6.881

Snyder, K. A., and Williams, D. G. (2003). Defoliation alters water uptake by deep and shallow roots of Prosopis velutina (Velvet Mesquite). Funct. Ecol. 17, 363-374. doi: 10.1046/j.1365-2435.2003.00739.x

Tubby, K. V., and Webber, J. F. (2010). Pests and diseases threatening urban trees under a changing climate. Forestry 83, 451-459. doi: 10.1093/forestry/cpq027

Vanderklein, D. W., and Reich, P. B. (1999). The effect of defoliation intensity and history on photosynthesis, growth and carbon reserves of two conifers with contrasting leaf lifespans and growth habits. New Phytol. 144, 121-132. doi: 10.1046/j.1469-8137.1999.00496.x

Vitali, V., Ramirez, J. A., Perrette, G., Delagrange, S., Paquette, A., and Messier, C. (2019). Complex above- and below-ground growth responses of two urban tree species following root, stem, and foliage damage - an experimental approach. Front. Plant Sci. 10:1100. doi: 10.3389/fpls.2019.01100

Wiley, E. (2013). Towards a Better Understanding of Nonstructural Carbohydrate Storage and Carbon Limitation in Trees. Ph.D dissertation. Philadelphia, PA: University of Pennsylvania.

Wiley, E., Casper, B. B., and Helliker, B. R. (2017). Recovery following defoliation involves shifts in allocation that favour storage and reproduction over radial growth in black oak. J. Ecol. 105, 412-424. doi: 10.1111/1365-2745.12672

Wiley, E., and Helliker, B. R. (2012). A re-evaluation of carbon storage in trees lends greater support for carbon limitation to growth. New Phytol. 195, 285-289. doi: 10.1111/j.1469-8137.2012.04180.x

Wiley, E., Huepenbecker, S., Casper, B. B., and Helliker, B. R. (2013). The effects of defoliation on carbon allocation: can carbon limitation reduce growth in favour of storage? Tree Physiol. 33, 1216-1228. doi: 10.1093/treephys/tpt093

Conflict of Interest: The authors declare that the research was conducted in the absence of any commercial or financial relationships that could be construed as a potential conflict of interest.

Publisher's Note: All claims expressed in this article are solely those of the authors and do not necessarily represent those of their affiliated organizations, or those of the publisher, the editors and the reviewers. Any product that may be evaluated in this article, or claim that may be made by its manufacturer, is not guaranteed or endorsed by the publisher.

Copyright ( 2021 Ramirez, Vitali, Martínez-Vilalta, Handa and Messier. This is an open-access article distributed under the terms of the Creative Commons Attribution License (CC BY). The use, distribution or reproduction in other forums is permitted, provided the original author(s) and the copyright owner(s) are credited and that the original publication in this journal is cited, in accordance with accepted academic practice. No use, distribution or reproduction is permitted which does not comply with these terms. 